DOI: https://doi.org/10.33989/2075-146x.2021.27.247070

УДК 373.5.043.2-056.2/.3

\title{
МАРИНА КОНОНОВА
}

ORCID: 0000-0002-2994-6866

Полтавський національний педагогічний університет імені В.Г. Короленка

\section{ДО ПИТАННЯ ПРО ЕКОЛОГІЗАЦЮ ОСВІТНЬОГО СЕРЕДОВИЩА В ІНКЛЮЗИВНИХ ЗАКЛАДАХ}

\begin{abstract}
У статті визначено роль педагогічної екології у системі освітньої практики в умовах інклюзії, розглянуто проблеми та перспективи екологізації освітнього середовища в контексті інклюзивної освіти. Досліджено особливості і рівень готовності (за результатами самооцінки в інтерв’ю) майбутніх учителів до професійної діяльності з дітьми з особливими освітніми потребами в умовах інклюзії.
\end{abstract}

Ключові слова: інклюзія, інклюзивна освіта, діти з особливими освітніми потребами, майбутні вчителі, екологізаџія, освітнє середовище, професійна діяльність

Постановка проблеми. Екологічна система включає в себе не тільки відносини між людиною і природою, а й взаємини між людьми, що є базисом педагогічної екології. Особлива актуальність цього питання постає в інклюзивній освіті. Саме навколишне середовище має надавати дітям з особливими освітніми потребами можливість здобувати освіту і сприяти їхньому розвитку незалежно від їх характеристик, нозології порушення психофізичного розвитку.

I хоча проблеми взаємодії школи і середовища неодноразово піднімалися педагогічною наукою i практикою, в більшості досліджень співвідношення освіти (виховання) і середовища розглядається переважно 3 позицій врахування впливу середовища на навчально-виховний процес. Однак, організація середовища, сприятливого для навчання і виховання школярів, процес не менш значущий. У зв'язку з вищезазначеним виникає нагальна потреба у необхідності створення екологічного інклюзивного освітнього середовища, що $\epsilon$ завданням сучасної освіти та одним із важливих шляхів реалізації концепції «Нова українська школа».

Аналіз останніх досліджень і публікацій свідчить про те, що загальні питання педагогічної екології, виокремлення основних наукових підходів до розуміння сутності екологізації, іiі особливостей у освітньому процесі, обгрунтування педагогічних умов створення еколого-орієнтованого простору сучасного загальноосвітнього навчального закладу розглядалися в наукових працях А. Застело (Застело, 2012), Т. Карібової (Карибова, 2002), М. Кириллової (Кириллова, 2012), Н. Морозової (Морозова, 2012), А. Нюдюрмагомедової (Нюдюрмагомедова, 2002), О. Пруцакової (Пруцакова, 2017) та ін.

Предметом педагогічної екології $є$ пошук закономірностей створення в освіті сприятливих умов для вільного відкритого спілкування, пізнання і розвитку учнів і встановлення меж дозволеного у взаєминах учнів, вчителів і учнів (Нюдюрмагомедова, 2002).

Педагогічна екологія і інклюзивна освіта є новими і актуальними і перспективними галузями педагогіки. Незаперечним є той факт, що основні принципи даних областей перегукуються і взаємно доповнюють один одного. Побудова інклюзивного освітнього простору неможлива без екологізації не тільки школи і шкільної спільноти, а й суспільства в цілому.

Створення сприятливого середовища для спілкування, навчання, розвитку дітей з особливими освітніми потребами; готовність педагога надати дітям можливість для відкритої поведінки, не порушуючи межі дозволеного; зниження тривожності і напруження; формування адекватної самооцінки; врахування психологічних і фізіологічних особливостей дітей; психолого-педагогічний супровід та підтримка дітей та їхніх сімей; використання потенціалу сім'ї; стимулювання ініціативи - це умови, які здатні створити сприятливе екологічне середовище для інклюзівної освіти (Кириллова, 2012).

Тож активне впровадження інклюзивного навчання в закладах загальної середньої освіти, модернізація й удосконалення вітчизняної системи вищої освіти детермінують основні підходи до фахової підготовки сучасного вчителя, робота якого полягає в навчанні, спілкуванні, психолого-педагогічній підтримці дітей 3 особливостями психофізичного розвитку.

Проблему підготовки педагогічних фахівців до навчання дітей з особливими освітніми потребами, як важливий психолого-педагогічний ресурс екологізації інклюзивного освітнього середовища, студіювали Ю. Бойчук, О. Казачінер (Бойчук, Казачінер, 2020), К. Бондар (Бондар, 2019), Е. Данілавічюте, С. Литовченко (Данілавічюте, Литовченко 2012), 3. Ленів (Ленів, 2014), П. Придатченко (Придатченко, 2006), А.Рацул, I. Шишова (Рацул, Шишова, 2011) та інші.

Вирізнення досі не вирішених аспектів наукової проблеми, яким і присвячено цю статтю. Таким чином, на основі аналізу науково-педагогічних праць із теми дослідження було встановлено, що, незважаючи 
на значний доробок у напрямі педагогічної екології, питання екологізації інклюзивного освітнього середовища, потребує обов'язкового розв'язання, оскільки є надзвичайно важливим та актуальним.

Мета дослідження - розкрити особливості екологізації освітнього середовища в контексті інклюзивної освіти.

Під час дослідження перед нами були поставлені такі питання: 1) яку роль відіграє педагогічна екологія у системі освітньої практики в умовах інклюзії; 2) які особливості і рівень готовності (за результатами самооцінки в інтерв’ю) майбутніх учителів до професійної діяльності з дітьми з порушеннями психофізичного розвитку в умовах інклюзії.

При проведенні цього дослідження був використаний комплекс загальнонаукових методів: теоретичні аналіз наукової літератури, порівняння, систематизація та узагальнення наукових результатів; емпіричні інтерв'ю в фокус-групах, педагогічне спостереження, самооцінка.

Виклад основного матеріалу. 3 метою розкриття теми екологізації освітнього середовища і $1 і ̈$ точок дотику з інклюзивною освітою, слід розглянути основну термінологію. Під інклюзивною освітою ми розуміємо таку систему освітніх послуг, при якій кожній людині, незалежно від наявних психофізичних, інтелектуальних, соціальних, емоційних та інших особливостей, надається можливість навчатися в загальноосвітніх установах.

Термін «інклюзія», як зазначено у документі «Міжнародні консультації з питань навчання дітей 3 особливими освітніми потребами», означає «політику та процес, який дає змогу всім дітям брати участь у всіх програмах» (Софій, Кавун, (Уклад.), 2006, с. 11), що за своїм концептуальним підходом визнає той факт, що ми змінюємо суспільство, щоби воно враховувало індивідуальні потреби людей і пристосовувалось до них, а не навпаки (Данілавічюте, Литовченко, 2012).

Методологія, спрямована на розвиток особистості кожної дитини з особливими освітніми потребами, що визнає його унікальність, неповторність та надає право на реалізацію різних потреб з урахуванням провідної для певного віку діяльності, є базовою для інклюзивного освітнього середовища.

Поняття «екологізація» має неоднозначне тлумачення. У контексті нашого дослідження, ми розглядаємо екологізацію як поняття, яке розкриває процес проникнення екологічного підходу, екологічних принципів у інклюзивну освітню сферу (Морозова, 2012).

Саме наявність в освітньому середовищі необхідних умов і ресурсів (в першу чергу грамотних фахівців) робить його інклюзивним освітнім середовищем для дітей з особливими освітніми потребами.

Основою екологізації освітнього середовища є екологічність освітнього простору, що дозволяє врахувати потреби учнів з різними психофізичними, інтелектуальними, емоційними, соціальними можливостями. Освітній простір можна розділити на внутрішній (indoor) і зовнішній (outdoor). До внутрішніх складових можна віднести: обладнання при вході, у холі, у класних кімнатах, у кімнатах відпочинку, в їдальні, а також екологічні правила поведінки у цих приміщеннях. До зовнішніх - освітні уроки і практики, в основах яких лежить взаємодія з природою.

Екологізація в контексті освітнього середовища виступає тим процесом, який перетворює освітнє середовище в більш привітну і привабливу для соціуму, навколишнього середовища і учнів.

Поняття розумного пристосування простору школи тісно пов'язане з аспектом доступності. Розумне пристосування здійснюється, коли продукт чи послуга вже створені, але є потреба їх адаптації щодо індивідуальних особливостей.

Універсальний дизайн в освіті - це дизайн усіх складових навчального процесу, в центрі його уваги $є$ школяр, студент. Дизайн враховує потреби усіх учнів, в тому числі з ООП, у створенні начального плану, програми, в оцінюванні знань, під час вибору методів викладання, розробці архітектурного дизайну школи, бібліотеки, спортивних майданчиків, гуртожитків, веб-сайтів, посадових інструкцій та навчальних матеріалів. На законодавчому рівні в Україні універсальний дизайн забезпечений документами: Закон України «Про освіту», ДБН В.2.2-17:2006 «Будинки і споруди. Доступність будинків і споруд для маломобільних груп населення». У Законі про освіту «універсальний дизайн» - це освітня стратегія, яка заснована не лише на перебудові простору школи та класу, а й на перебудові стратегії викладання на уроці (Бондар, 2019).

Говорячи про екологізацію навчального процесу, в першу чергу хотілося б звернути увагу на досвід скандинавських країн, які вже давно взяли цей напрямок. У Данії люблять говорити: «Може, ми не найрозумніші, але ми - найщасливіші». Такий вислів ні в якому разі не принижує датську освітню систему, а швидше піднімає іï, так як вона дозволяє кожному індивіду знайти своє місце в соціумі, незалежно від розумових або фізичних здібностей, задатків і навичок. Кожен учень датської школи навчаючись, розуміє, що він придбає професію, яка буде затребувана, забезпечить його незалежністю і через яку він зможе знайти своє місце в соціумі. Якщо в учня невисокий інтелект, він не стане юристом, лікарем або психологом, але він завжди буде мати можливість вибору іншої професії, затребуваною державою. В цьому і є екологізацію освітньої системи в кооперації з підприємствами, що надають робочі місця. Що стосується людей 3 обмеженими психофізичними можливостями, то вони включені в соціум Данії на природному рівні. У тому числі і в освітню систему. Самі датські будівлі дуже екологічні, вони максимально враховують різні можливості людей і їх 
потреби, від міні-ліфтів в місцях, де є найменші сходинки, до меблів, яку використовують учні (Кононова, Васина, Кононов, 2020).

Порівнюючи інклюзивну культуру нашої країни і скандинавських країн (Данії, Фінляндії, Швеції), можна помітити, що ми схильні добудовувати пандуси при будівництві нової школи, а у них схильні будувати без сходинок, так щоб вхід був на одному рівні. У підході скандинавських культур менше поділу, що забезпечує почуття інклюзивності, включеності в соціум. Підсумовуючи, можна помітити, що екологізація освітнього середовища починається з екологічності будівель і меблів в освітніх установах.

Ми солідарні з особливостями Датської системи освіти в тому, що основним завданням педагогічної екології в контексті інклюзивної освіти $є$ створення екологічно безпечного розвивавального середовища для дітей з особливими освітніми потребами. Ефективними екологічними освітніми технологіями в умовах інклюзії $€$ такі, які не шкодять фізичному, психічному і моральному здоров'ю учнів.

Введення інклюзивної освіти в Україні сприяє створенню цілісної системи підтримки, заснованої на екологічному підході, який поєднує дітей і педагогів і сконцентрований на можливостях, а не на обмеженнях дітей, забезпечує диференціальний психолого-педагогічний супровід дітей з особливими освітніми потребами.

Сформульовані Т. Карібовою (Карибова, 2002) умови для реалізації принципів педагогічної екології в початковій освіті, на наш погляд, можна адаптувати і до інклюзивної освіти:

- розуміння педагогічними кадрами значущості педагогічної екології в практиці інклюзивної освіти;

- знання вчителями, психологами, дефектологами, лікарями методів виявлення та оцінки стану учнів 3 особливими освітніми потребами;

- готовність педагогічних кадрів до використання екологічних засобів, які дозволяють знизити напруженість і створити сприятливі умови для ефективного пізнання і вільних стосунків в освітньому середовищі;

- здатність вчителів створювати класи, в яких оптимально інтегровані зміст навчального матеріалу і засоби педагогічної екології;

- знання вчителями технологій використання принципів педагогічної екології;

- навички викладачів, досвід і педмайстерність, застосування педагогічного моніторингу новоутворень в пізнанні, свобода відносин і самореалізації в екологічно чистому педагогічному середовищі;

- наявність у вчителів, психологів, дефектологів, лікарів екологічної позиції в постановці цілей, їх реалізації та оцінці ходу і результатів розвитку та виховання дітей з особливими освітніми потребами (Карибова, 2002).

Керуючись системоутворюючими принципами педагогічної екології (екологічність, гуманність і культурна доцільність), в нашій позиції виділяються наступні області відносин, де потрібна увага до дітей з особливими освітніми потребами: 1) врахування особливостей психофізичної сфери і розвитку дитини 3 особливими освітніми потребами; 2) використання факторів оздоровчої освіти; 3) моральні аспекти педагогічної взаємодії; 4) стимулювання засвоєння екологічних звичок в освітньому середовищі.

Сказане вище підтверджує, що успіх інклюзивної освіти багато в чому залежить від вмілого застосування комплексу психолого-педагогічних ресурсів, зокрема, професійної компетентності вчителів, реорганізації системи професійної підготовки майбутніх фахівців у напрямку професійного співробітництва в умовах інклюзії, що заслуговує на особливу уваги в контексті нашого дослідження.

На початку вивчення проблеми ми поставили питання виявлення готовності майбутніх вчителів працювати 3 дітьми 3 порушеннями психофізичного розвитку та знання фахівцями технологій використання принципів педагогічної екології.

Оскільки фокус-групи призначені для виявлення спектра думок з досліджуваної проблеми, пошуку пояснення поведінки людей в тих чи інших ситуаціях, для визначення зазначених аспектів було проведено інтерв’ю в фокус-групах (групи студентів - майбутніх вчителів, групи кураторів, змішані групи).

Аналіз результатів відповідей на ключові питання сценарію (фокус-групова дискусія проводилася у другому семестрі IV курсу навчання майбутніх вчителів хореографії, образотворчого мистецтва, музики) показав наступне.

Із запропонованих варіантів відповідей на запитання «Наскільки у Вас сформована професійна установка на готовність працювати 3 дітьми 3 порушеннями психофізичного розвитку за різними нозологіями?» лише $22,7 \%$ студентів оцінили свою сформованість професійної установки на готовність працювати 3 дітьми 3 порушеннями психофізичного розвитку як «повністю сформована». Основна кількість майбутніх вчителів зазначила, що «не в повній мірі сформована, в залежності від нозології порушення» - 50,3\%, «не сформована» $-20 \%$.

На наступне запитання «Як Ви оцінюєте рівень Ваших теоретичних знань 3 професійно орієнтованих дисциплін, необхідних для роботи з дітьми з порушеннями психофізичного розвитку?», яке обговорювалося у фокус-групах, отримано такі результати: $18,3 \%$ майбутніх вчителів оцінили свій рівень теоретичних знань 3 професійно орієнтованих дисциплін, необхідних для роботи з дітьми з порушеннями психофізичного розвитку як високий; 51, 7 \% - як середній рівень, а $30 \%$ - як низький рівень теоретичних знань 3 професійно орієнтованих дисциплін, необхідних для роботи з дітьми з порушеннями психофізичного розвитку. Вважаємо, що досить 
високий відсоток низького рівня свідчить про необхідність переорієнтації освітнього процесу на додаткове введення дисциплін з інклюзії та впровадження інтерактивних методик.

Відповіді на запитання «Чи вважаєте Ви, що отримані під час навчання практичні знання та вміння достатні для кваліфікованої роботи на посаді вчителя в інклюзивному закладі освіти?» розподілилися наступним чином: 22,22\% респондентів відповіли «так», 38,35\% віддали перевагу відповіді «частково», 39,43\% студентів вважають, що ні. Обговорення обраних відповідей уможливило зафіксувати, що студенти вважають, що у процесі фахової підготовки у ЗВО варто більше уваги приділяти практичному навчанню, можливостям практикуватися в інклюзивних закладах освіти, навчально-виховних комплексах, реабілітаційних центрах.

Відповіді на запитання «Підкресліть ознаки своєї готовності до креативної, інноваційної професійної діяльності в умовах інклюзивного середовища» засвідчили такі результати самооцінки майбутніх вчителів: 53,40\% студентів відомі нові педагогічні ідеї, що свідчить про те, що викладачі «ідуть в ногу 3 часом» і знайомлять своїх вихованців з передовим педагогічним досвідом та новітніми методиками інклюзивного навчання; 46,6\% стверджують, що їм притаманне нестандартне мислення. Щодо останнього твердження, студенти зазначали, що цікавилися поняттям «нестандартне мислення», читали відповідну літературу в Інтернеті, із цікавості проходили тести на нестандартне мислення, i, відповідно, вважають його корисною навичкою, а в своєму житті намагаються руйнувати шаблони, дивитися на проблеми з різних точок зору, розкривати свій потенціал.

Думки студентів при обговоренні питань «Які емоції виникали у Вас при першому практичному досвіді в роботі з дітьми з порушеннями психофізичного розвитку?» та «Які емоції Вас супроводжують зараз при роботі 3 дітьми з порушеннями психофізичного розвитку?» віддзеркалилися у змішаному спектрі: це і радість та задоволення від роботи; і тривожність, і невпевненість у рівні професійної підготовки, і надмірна жалість до таких дітей, бажання допомогти, навчити, підтримати, сказати «все буде добре, разом ми все подолаємо». Водночас, кожен зі студентів відчував і певний страх у спілкуванні з дітьми, їхніми батьками, невпевненість, брак знань та досвіду ефективної комунікації. Було зафіксовано і поодинокі випадки, коли студенти відчували роздратованість, демонстрували нестриманість, нетактовність.

На запитання «Визначте власний рівень умінь (високий, середній, низький) з навчання дітей з особливими освітніми потребами» самооцінювання студентів продемонструвало такі результати: 16,79\% студентів вважають, що вони володіють високим рівнем, 45,27\% - середнім та 37,94\% - низьким.

За результатами ранжування запропонованих варіантів відповідей на запитання «Яким формам організації навчання у ЗВО, професійного розвитку Ви надаєте перевагу? Визначте в порядку ієрархії: лекціям; практичним заняттям; практико-орієнтованим семінарам; навчальним практикам; воркшопам; майстер-класам; творчим лабораторіям; сертифікаційним курсам; супервізії; індивідуальному консультуванні педагогів; участі у науковопрактичних конференціях; тренінгам; самоосвіті» ми отримали таку картину: пріоритетне місце лекціям у процесі фахової підготовки віддали 2,47\% студентів; практичним заняттям - 9,90\% студентів; практикоорієнтованим семінарам - 14,23\%; навчальним практикам - 42,06\%; воркшопам - 71,75\%; майстер-класам $78,56 \%$; творчим лабораторіям - 54,43\%; сертифікаційним курсам - 84,95\%; супервізії - 82,89\%; індивідуальному консультуванню педагогів - 38,14\%; участі у науково-практичних конференціях - 11,13\%; тренінгам - 69,48\%; самоосвіті - 27,36\% опитаних респондентів.

Аналізуючи результати бачимо, що перше місце у рейтингу форм організації навчання та професійного розвитку у ЗВО займають сертифікаційні курси (54,95\%), яким студенти першочергово надають перевагу, друге - супервізії (82,89\%), третє - майстер-класи (78,56\%), четверте - воркшопи (71,75\%), п’яте - тренінги (69,48\%). На жаль, студенти недооцінюють роль науково-дослідної роботи у процесі професійного розвитку та самоосвіти, що зумовлює необхідність посилення мотивації майбутніх вчителів до таких видів навчальної діяльності. Найнижчий відсоток спостерігається у лекцій $(2,47 \%)$, що свідчить про те, що майбутні вчителі, основа професійної діяльності яких є діалог та інтеракція, вважають недоречним та неефективним традиційний виклад теоретичного матеріалу (здебільшого, монолог викладача, у кращому випадку унаочнений презентацією), і хочуть відвідувати інтерактивні лекції, які базуються на сучасних інтерактивних методиках. Удосконалення потребує і дидактичний інструментарій практичних занять, семінарів, навчальних практик, індивідуальних консультацій з викладачами.

Дискусія навколо запитання «Які особистісні риси мають бути притаманні вчителю інклюзивного осітнього закладу? Чи є ці якості у Вас?» у підсумку засвідчила, що студенти до таких рис відносять любов до дітей, чесність, терпіння, витриманість, комунікативність, доброзичливість, здатність викликати довіру, почуття гумору, оптимізм, бадьорість духу, спостережливість, здатність до навіювання та співпереживання, вміння схиляти на свій бік, ерудицію, креативність, стресостійкість, дружелюбність, високу працездатність, порядність. Особливо студенти наголошують на педагогічній майстерності, педагогічному такті, готовності до непередбачуваних ситуацій та пошуку конструктивного виходу з них, що становить основу професіоналізму вчителя.

Висновки і перспективи досліджень. Отже, екологізація освітнього середовища в контексті інклюзивної освіти має певне значення для роботи 3 дітьми 3 особливими освітніми потребами. Основне завдання 
педагогічної екології в умовах інклюзивної освіти - це створення екологічно благополучного розвивального середовища для дітей з ООП. Від вчителів потребується спеціальна підготовка, так як їх роль полягає у створенні цілісної системи підтримки, заснованої на екологічному підході, що робить акцент на можливостях, а не на обмеженнях даної категорії дітей. Крім того, педагогічна екологія дозволяє підвищити гуманістичну спрямованість вчителів інклюзивних класів.

За результатами застосування методу інтерв’ю у фокус-групах, проведених з майбутніми вчителями, у цілому зафіксовано позитивне ставлення як викладачів, так і студентів, до необхідності цілеспрямовано організованого процесу професійної підготовки майбутніх учителів до роботи в інклюзивних освітніх закладах, який передбачає створення для цього спеціальних педагогічних умов. Досить високий відсоток низького рівня теоретичних знань і практичних вмінь, достатніх для кваліфікованої роботи 3 дітьми з ООП свідчить про необхідність переорієнтації освітнього процесу на введення вибіркових дисциплін 3 інклюзії, практик в інклюзивних освітніх закладах.

Перспективи дослідження полягають у розробці та експериментальній перевірці педагогічних умов професійної підготовки майбутніх учителів до роботи з дітьми з ООП.

\section{Список використаних джерел}

Бойчук, Ю. Д., Казачінер, О. С. (2020). Зміст підготовки майбутніх фахівців до формування комунікативної діяльності дітей з особливими освітніми потребами. Витоки педагогічної майстерності, 25, 12-20.

Бондар, К. М. (Упоряд.) (2019). Теорія і практика інклюзивної освіти: навч.-метод. посіб. Кривий Ріг.

Данілавічюте, Е. А., Литовченко, С. В. (2012). Стратегї викладання в інклюзивному навчальному закладі: навч.метод. посіб. Київ: А.С.К.

Застело, А. О. (2012). Екологізація освітньої взаємодії. Вісник Одеського національного університету. Психологія, $17(9), 90-97$.

Карибова, Т. Т. (2002). Условия реализации принщипов педагогической экологии в начальной школе. (Дис. канд. пед. наук). Махачкала.

Кириллова, М. И. (2012). Экологический подход в инклюзивном образовании. Вектор науки ТГУ, 3 (10), $112-114$.

Кононова, М., Васина, М., Кононов, Б. (2020). Проблемы и перспективы экологизации образовательной среды в контексте инклюзивного образования. Zdrowie - edukacja - społeczeństwo Perspektywa międzynarodowa, Wydawnictwo Uczelniane WSG, Bydgoszcz, 393-413.

Ленів, 3. (2014). Підготовка кадрів для створення оптимальних умов дітям з порушеннями психофізичного розвитку в інклюзивному середовищі. Особлива дитина: навчання і виховання, 3, 13-19.

Морозова, Н. В. (2012). Экологизация образования как средство формирования экологической культуры. Фундаментальные исследования, 3, 2, 300-304.

Нюдюрмагомедова, А.Н. (2002). Основы педагогической экологии: монография. Махачкала: ИПЦ ДГУ.

Пруцакова, О. Л. (2017). Сутність і педагогічні умови екологізації освітнього простору. Теоретико-методологічні проблеми виховання дітей та учнівської молоді, 21(2), 187-197.

Софій, Н., Кавун, Ю. (Уклад.). (2006). Як досягати змін: посібник для батьків і педагогів з обстоювання та захисту прав дітей з особливими освітніми потребами та громадської діяльності. Київ: ФО-П Придатченко П.М.

\section{References}

Boichuk, Yu. D., \& Kazachiner, O. S. (2020). Zmist pidhotovky maibutnikh fakhivtsiv do formuvannia komunikatyvnoi diialnosti ditei z osoblyvymy osvitnimy potrebamy [The content of training future professionals for the formation of communicative activities of children with special educational needs]. Vytoky pedahohichnoi maisternosti [The origins of pedagogical skills], 25, 12-20 [in Ukrainian].

Bondar, K. M. (Comp.) (2019). Teoriia i praktyka inkliuzyvnoi osvity [Theory and practice of inclusive education]: navchalnometodychnyi posibnyk. Kryvyi Rig [in Ukrainian].

Danilavichiute, E. A., \& Lytovchenko, S. V. (2012). Stratehii vykladannia v inkliuzyvnomu navchalnomu zakladi [Teaching strategies in an inclusive school]: navchalno-metodychnyi posibnyk. Kyiv: A.S.K. [in Ukrainian].

Karibova, T. T. (2002). Usloviia realizatcii printcipov pedagogicheskoi ekologii v nachalnoi shkole [Conditions for the implementation of the principles of educational ecology in primary school]. ( $\mathrm{PhD}$ diss.). Makhachkala [in Russian].

Kirillova, M. I. (2012). Ekologicheskii podkhod v inkliuzivnom obrazovanii [Conditions for the implementation of the principles of pedagogical ecology in primary school]. Vektor nauki TGU [TSU science vector], 3 (10), 112-114 [in Russian].

Kononova, M., Vasina, M., \& Kononov, B. (2020). Problemy i perspektivy ehkologizacii obrazovatel'noj sredy v kontekste inklyuzivnogo obrazovaniya [Problems and prospects of greening the educational environment in the context of inclusive education]. Zdrowie - edukacja-społeczeństwo Perspektywa międzynarodowa, Wydawnictwo Uczelniane WSG, Bydgoszcz, 393-413 [in Ukrainian, in Poland].

Leniv, Z. (2014). Pidhotovka kadriv dlia stvorennia optymalnykh umov ditiam z porushenniamy psykhofizychnoho rozvytku $\mathrm{v}$ inkliuzyvnomu seredovyshchi [Training to create optimal conditions for children with mental and physical disabilities in an inclusive environment]. Osoblyva dytyna: navchannia $i$ vykhovannia [Special child: education and upbringing], 3, 13-19 [in Ukrainian]. 
Morozova, N. V. (2012). Ekologizatciia obrazovaniia kak sredstvo formirovaniia ekologicheskoi kultury [Greening of education as a means of forming ecological culture]. Fundamentalnye issledovaniia [Basic research], 3, 2, 300-304 [in Russian].

Nyudyurmagomedova, A. N. (2002). Osnovy pedagogicheskoj ehkologii [Fundamentals of pedagogical ecology]: monografiya. Makhachkala, IPC DGU [in Russian].

Prutsakova, O. L. (2017). Sutnist i pedahohichni umovy ekolhizatsii osvitnoho prostoru [The essence and pedagogical conditions of greening of educational space]. Teoretyko-metodolohichni problemy vykhovannia ditei ta uchnivskoi molodi [Theoretical and methodological problems of raising children and students], 21 (2), 187-197 [in Ukrainian].

Sofii, N., \& Kavun, Yu. (Comps.). (2006). Yak dosiahaty zmin [How to achieve change]: posibnyk dlia batkiv i pedahohiv z obstoiuvannia ta zakhystu prav ditei z osoblyvymy osvitnimy potrebamy ta hromadskoi diialnosti. Kyiv: FO-P Prydatchenko P.M. [in Ukrainian].

Zastelo, A. O. (2012). Ekolohizatsiia osvitnoi vzaiemodii [Greening of educational interaction]. Visnyk Odeskoho natsionalnoho universytetu. Psykholohiia [Bulletin of Odessa National University. Psychology], 17 (9), 90-97 [in Ukrainian].

\section{KONONOVA M.}

Poltava V. G. Korolenko national pedagogical University, Ukraine

\section{ON THE QUESTION OF ECOLOGIZATION OF THE EDUCATIONAL ENVIRONMENT IN INCLUSIVE INSTITUTIONS}

The article defines the role of pedagogical ecology in the system of educational practice in the conditions of inclusion. The term "inclusion", the concept of "greening", the definition of universal design in education and reasonable adaptation of school space are revealed. Problems and prospects of greening of the educational environment in the context of inclusive education are considered. Comparing the inclusive culture of our country and the Scandinavian countries, it is noted that the approach of Scandinavian cultures is more to ensure inclusiveness, inclusion in society. The conditions for the implementation of the principles of pedagogical ecology in inclusive education are determined.

It is proved that the success of inclusive education largely depends on the professional competence of teachers, the reorganization of the system of professional training of future professionals. The features and level of readiness (according to the results of self-assessment in the interview) of future teachers for professional activity with children with special educational needs in the conditions of inclusion are studied. The positive attitude of students to the need for purposefully organized process of their professional preparation for work in inclusive educational institutions is recorded.

Key words: inclusion, inclusive education, children with special educational needs, future teachers, greening, educational environment, professional activity

Стаття надійшла до редакції 02.02.2021 p. 